Bioedusiana

Vol. 02, No. 01, Sep 2017

ISSN $2477-5193$

\title{
UPAYA MENINGKATKAN HASIL BELAJAR SISWA \\ DENGAN MENGGUNAKAN MODEL PEMBELAJARAN KOOPERATIF \\ TIPE STUDENT TEAMS ACHIEVEMENT DIVISIONS (STAD) \\ DENGAN BANTUAN MEDIA POWERPOINT \\ PADA KONSEP EKOSISTEM
}

(Penelitian Tindakan Kelas di Kelas VII D SMP Negeri 2 Tasikmalaya

Tahun Ajaran 2010-2011)

\author{
Diki Muhamad Chaidir ${ }^{1)}$, Endang Surahman ${ }^{1)}$, Siti Kamisah $^{2)}$ \\ 1) Jurusan Pedidikan Biologi Fakultas Keguruan dan Ilmu Pendidikan \\ Universitas Siliwangi Tasikmalaya \\ J1. Siliwangi No. 24 Kota Tasikmalaya 46115 \\ ${ }^{2}$ SMP Negeri 2 Kota Tasikmalaya \\ Jl. Alun-Alun Kab. No. 1 Kel.Empangsari Kec. Tawang Kota Tasikmalaya 46113 \\ Email: dikimc@unsil.ac.id
}

\begin{abstract}
The aimed of this research was to determine the improvement of student learning outcomes by using cooperative learning model type student teams achievement divisions with the help of powerpoint media on the concept of ecosystem. The method used in this research is classroom action research method. The design of this study using the spiral model as much as 3 cycles. Each cycle is done in accordance with the learning scenario and for the next cycle based on the results of previous cycle reflection. The research data was collected by instrument in the form of observation sheet, learning result test and an interview guide. Based on the analysis of the research results, it can be seen that there is an increase in student learning outcomes from cycle I to cycle II and from cycle II to cycle III. The first test of the first cycle has an average score of 5.73, the initial test of cycle II has an average score of 7.30 and the initial test of cycle III 7.68. After students get learning by using cooperative learning model type student teams achievement divisions with the help of media powerpoint. The final test of a cycle I have an average score of 8.82, the final test of cycle II has an average score of 9.30 and the final test of cycle III has an average score of 9.41. This study concluded that the use of cooperative learning model type student teams achievement divisions with the help of media powerpoint on the concept of ecosystem can improve student learning outcomes in class VII D SMP Negeri 2 Tasikmalaya.
\end{abstract}

Keywords: student team achievement divisions, student learning outcomes, ecosystem

\begin{abstract}
ABSTRAK
Penelitian ini bertujuan untuk mengetahui peningkatan hasil belajar siswa dengan menggunakan model pembelajaran kooperatif tipe student teams achievement divisions dengan bantuan media powerpoint pada konsep ekosistem. Dengan jumlah siswa sebanyak 44 orang. Metode yang digunakan dalam penelitian ini adalah metode penelitian tindakan kelas. Desain penelitian ini menggunakan model spiral sebanyak 3 siklus. Setiap siklus dilakukan tindakan sesuai dengan skenario pembelajaran dan untuk siklus selanjutnya berpedoman dari hasil refleksi
\end{abstract}


Bioedusiana

Vol. 02, No. 01, Sep 2017

ISSN $2477-5193$

siklus sebelumnya. Data penelitian dikumpulkan dengan instrumen berupa lembar observasi, tes hasil belajar dan pedoman wawancara. Berdasarkan analisa dari hasil penelitian, dapat diketahui bahwa terdapat peningkatan hasil belajar siswa dari siklus I ke siklus II dan dari siklus II ke siklus III. Tes awal siklus I mempunyai skor rata-rata 5,73, tes awal siklus II mempunyai skor rata-rata 7,30 dan tes awal siklus III 7,68. Setelah siswa mendapatkan pembelajaran dengan menggunakan model pembelajaran kooperatif tipe student teams achievement divisions dengan bantuan media powerpoint. tes akhir siklus I memiliki skor ratarata 8,82 , tes akhir siklus II memiliki skor rata-rata 9,30 dan tes akhir siklus III memiliki skor rata-rata 9,41. Penelitian ini menyimpulkan bahwa penggunaan model pembelajaran kooperatif tipe student teams achievement divisions dengan bantuan media powerpoint pada konsep ekosistem dapat meningkatkan hasil belajar siswa di kelas VII SMP Negeri 2 Tasikmalaya.

Kata Kunci: student team achievement divisions, hasil belajar siswa, ekosistem

\section{PENDAHULUAN}

Indonesia merupakan salah satu negara yang sedang berkembang. Pembangunan di berbagai aspek mulai ditingkatkan. Peningkatan kualitas sumber daya manusia merupakan prasyarat mutlak untuk mencapai sebuah tujuan pembangunan. Dalam hal ini pendidikan mempunyai peranan sangat penting dalam mempersiapkan sumber daya manusia yang berkualitas. Untuk mewujudkan hal tersebut perlu dilakukan secara menyeluruh, terarah dan terpadu diberbagai bidang pendidikan.

Proses pendidikan indonesia sangat dipengaruhi peran guru dalam kegiatan belajar mengajar. Karena untuk membentuk seorang individu yang dapat berfikir secara kritis, logis dan sistematis tidaklah mudah. Perlu dilakukan pengembangan yaitu diperlukan kecakapan guru dalam menentukan model pembelajaran yang mungkin dapat menuntun proses belajar mengajar dengan meningkatkan hasil belajar. Selain itu, perlu diperhatikan kondisi siswa yang akan dihadapi dengan kemampuan intelektual yang berbeda-beda.

Dengan menggunakan pembelajaran kooperatif dapat membantu antar siswa untuk lebih memudahkan berkomunikasi dan saling berinteraksi. Dalam model ini siswa diarahkan untuk biasa bekerja sama dengan lingkungan sosialnya, mengembangkan diri dan tanggung jawab secara individual.

Penambahan media dalam proses penyampaian materi diharapkan bisa membantu dalam tahap penyampaian materi pembelajaran kooperatif. Perkembangan di bidang teknologi pembelajaran terus ditingkatkan di berbagai sekolah. Media bisa dimanfaatkan untuk menambah ketertarikan siswa terhadap materi yang disampaikan oleh guru. 
Bioedusiana

Vol. 02, No. 01, Sep 2017

ISSN $2477-5193$

Berdasarkan hasil observasi di lapangan, melalui wawancara dengan guru mata pelajaran biologi di SMP Negeri 2 Tasikmalaya, diperoleh permasalahan yang dihadapi siswa dalam proses belajar mengajar. Dalam kegiatan belajar mengajar guru lebih banyak menerapkan model pembelajaran yang konvensional dengan menggunakan metode ceramah. Sehingga Siswa kurang memahami materi yang telah sampaikan oleh guru yang menerapkanan model pembelajaran yang konvensional dengan menggunakan metode ceramah. Hal tersebut dapat dilihat dari hasil belajar siswa kelas VII tahun ajaran 2009-2010 pada konsep ekosistem dengan hasil belajarnya belajarnya hanya mencapai 70 sedangkan nilai kriteria ketuntasan minimum (KKM) pada mata pelajaran biologi pada konsep ekosistem harus mencapai 75 di sekolah tersebut. Sehingga pembelajaran dengan menggunakan metode ceramah di kelas VII D SMP Negeri 2 Tasikmalaya belum tuntas.

Sehubungan dengan hal tersebut, salah satu alternatif yang digunakan untuk mengatasi kesulitan- kesulitan siswa dalam penguasaan terhadap konsep biologi yakni dengan menerapkan model pembelajaran kooperatif tipe student teams achievement divisons dengan bantuan media powerpoint.

\section{METODE PENELITIAN}

Metode penelitian yang digunakan adalah metode tindakan kelas (classroom action research), yang mana penelitian itu merupakan salah satu jenis penelitian yang dapat digunakan oleh pengajar dalam pelaksanaan program pengajaran. Kelas merupakan tempat yang digunakan oleh para pengajar untuk melakukan penelitian demi memperbaiki kinerja mereka dalam proses belajar mengajar. Metode yang terdapat dalam penelitian ini adalah metode deskriptif karena berusaha menggambarkan masalah-masalah yang terjadi dikelas saat pelajaran berlangsung.

\section{Variabel Penelitian}

Variabel bebas dalam penelitian ini adalah Model pembelajaran koopertaif tipe student team achievement divisons dengan bantuan media powerpoint. Variabel terikat dalam penelitian ini adalah hasil belajar siswa.

\section{Desain Penelitian}

Dalam penelitian tindakan kelas ini, menggunakan model siklus spiral. Model siklus seperti ini terdiri dari tiga siklus yang setiap siklusnya terdapat empat tahapan, yaitu perencanaan, pelaksanaan tindakan, pengamatan, dan refleksi. Adapun model spiral tindakan kelas yang digunakan dalam penelitian ini 
Bioedusiana

Vol. 02, No. 01, Sep 2017

ISSN $2477-5193$

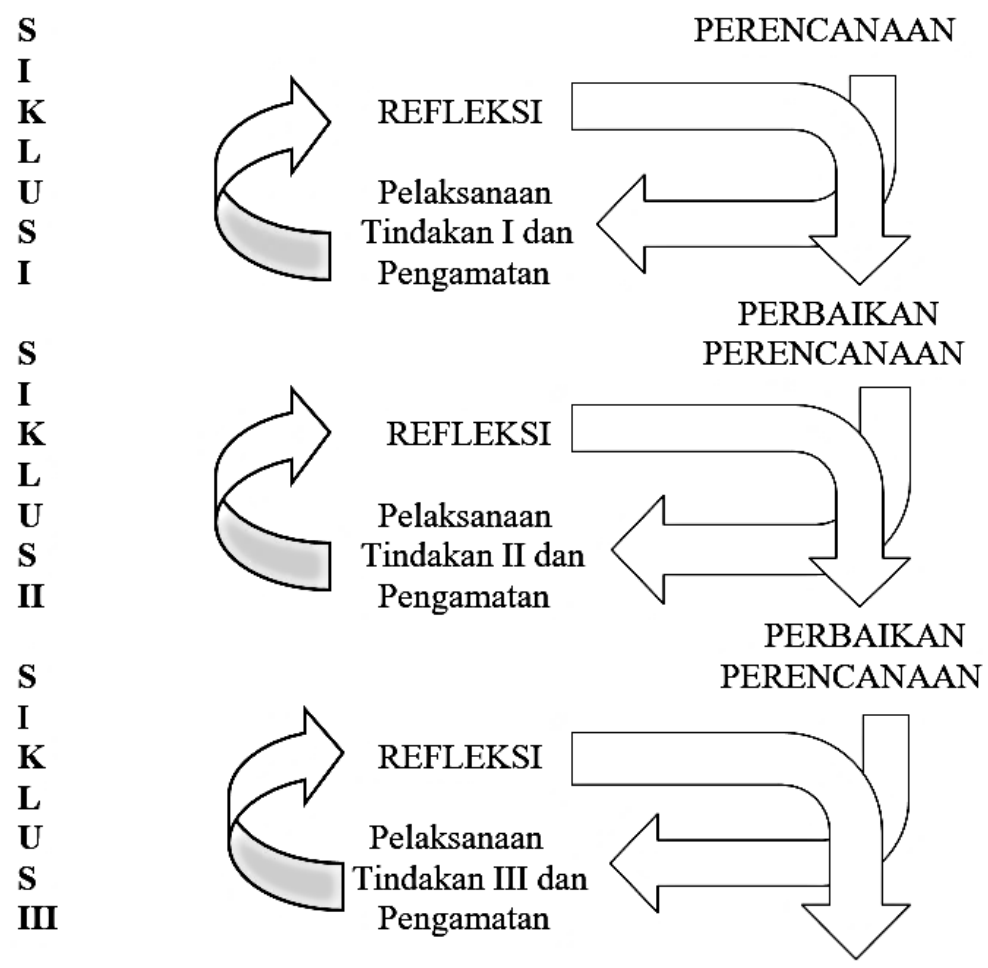

Gambar 1. Spiral Penelitian Tindakan Kelas

Sumber: Hopkins (Surahman, Endang, 2005:10)

\section{Perencanaan}

Berdasarkan pada pengalaman, pengamatan, dan identifikasi masalah yang dilakukan, pada tahap ini peneliti memilih model pembelajaran yang dianggap cocok untuk memperbaiki dan meningkatkan hasil belajar pada konsep ekosistem. Rencana ini mencakup semua langkah tindakan secar rinci, mulai dari materi/ bahan ajar, rencana pelajaran yang mencakup model pembelajaran, teknik, dan instrumen yang digunakan.

\section{Tindakan}

Tahapan ini merupakan implementasi (pelaksanaan) dari tahap perencanaan yang telah disusun sebagai upaya meningkatkan hasil belajar pada konsep ekosistem.

Langkah-langkah yang dilakukan selama tahap ini peneliti melibatkan orang lain dalam hal ini rekan sejawat sebagai observer guna membantu mempertajam refleksi dan evaluasi.

\section{Observasi}

Kegiatan tahap observasi
dilakukan bersamaan dengan
pelaksanaan tahap tindakan yang
dilakukan oleh observer. Data yang
dikumpulkan pada tahap ini berisi
tentang pelaksanaan tahap
perencanaan dan tindakan yang telah
disusun dengan maksud untuk
mengetahui apakah pelaksanaan
proses yang telah disusun tersebut
sudah tercapai atau belum pada
sasaran atau tujuan.




\section{Refleksi}

Hasil yang diperoleh dalam tahap observasi dikumpulkan dan dianalisis berdasarkan hasil analisis tersebut peneliti dapat melihat hasilnya dan menyimpulkan apakah tujuan sudah tercapai atau belum. Jika tujuan belum tercapai, maka berdasarkan hasil tersebut peneliti kemudian merefleksikan dengan cara menyusun kembali perencanaan untuk perbaikan selanjutnya yang dilaksanakan pada siklus berikutnya.

\section{Teknik Pengolahan dan Analisis Data}

Di dalam penelitian ini, data yang diperoleh dari tahap-tahap yang dilaksanakan sebelumnya dilakukan pengolahan dan analisis data, sehingga didapat hasil penelitian.

\section{Analisis hasil belajar}

Analisis mengenai data hasil tes belajar siswa akan menggunakan teknik deskriptif dan persentase ratarata. Mean atau rata-rata diperoleh dengan menjumlahkan seluruh skor dibagi dengan banyaknya subjek (Sudjana, Nana, 2005:109).

Secara sederhana, rumusnya adalah sebagai berikut:

$$
\bar{X}=\frac{\sum X}{N}
$$

Keterangan :

$$
\begin{aligned}
\bar{X} & =\text { Rata-rata (mean) } \\
\sum X & =\text { Jumlah seluruh skor } \\
\mathrm{N} & =\text { Banyaknya subjek }
\end{aligned}
$$

\section{Analisis hasil observasi siswa dan guru}

Analisis hasil observasi terhadap siswa dan guru, baik aktivitas maupun tindakannya pada setiap siklus akan menggunakan teknik deskriptif karena berusaha menggambarkan permasalahan yang terjadi pada saat penelitian dilaksanakan.

\section{Analisis hasil wawancara terbuka kepada siswa}

Analisis hasil wawancara terbuka kepada siswa akan menggunakan teknik deskriptif karena berusaha menggambarkan permasalahan yang terjadi pada saat penelitian dilaksanakan.

\section{HASIL DAN PEMBAHASAN}

Hasil dan pembahasan penelitian dilihat dari tes kognitif, observasi dan wawancara.

\section{Siklus I}

Pada perencanaan di Siklus I, guru menyiapkan seluruh perangkat pembelajaran. Tes kognitif dilaksanakan pada awal sebelum pembelajaran dimulai dan pada akhir siklus pembelajaran. Dalam hal ini tes awal dan akhir yang diberikan berbeda.

Berikut ini adalah data hasil ratarata pre-test dan post-test yang telah diperoleh berdasarkan tes siklus I.

Tabel 1. Jumlah skor dan rata-rata pre-test dan post-test pada siklus I

\begin{tabular}{lcc}
\hline Data & Pre-test & Post-test \\
\hline $\begin{array}{l}\text { Jumlah } \\
\text { Skor }\end{array}$ & 252 & 388 \\
\hline Rata-rata & 5,73 & 8,82 \\
\hline
\end{tabular}


Bioedusiana

Vol. 02, No. 01, Sep 2017

ISSN $2477-5193$

Berdasarkan data pada tabel 1 . terlihat peningkatan hasil belajar siswa. Akan tetapi nilai masingmasing siswa tersebut jika dikalikan dengan sepuluh, akan ada siswa yang nilai tes akhirnya (post-test) masih dibawah kriteria ketuntasan minimal sebesar 75, sebelum masuk ke siklus II, diadakan remedial terlebih dahulu terhadap siswa-siswa tersebut dengan kembali melakukan perlakuan di luar jam pelajaran sekolah dan kembali melakukan tes dengan soal yang sama dengan soal tes akhir (post-test) pada siklus I.

Hasil observasi terhadap guru dilakukan oleh observer yaitu guru mata pelajaran IPA kelas VII SMP Negeri 2 Tasikmalaya, Siti Kamisah, S.Pd. Adapun hasil observasinya menunjukan guru sudah cukup baik dalam mempersiapkan bahan belajar akan tetapi masih kurang efektif dalam waktu, serta dalam proses pembelajaran secara garis besar guru sudah cukup menguasai berlangsungnya proses pembelajaran. Hasil observasi terhadap siswa terlihat partisipasi dan aktivitas belajar masih ada siswa yang malu dalam mengemukakan pendapatnya, serta sikap siswa yang masih kurang peduli terhadap proses pembelajaran dan sering bercanda dengan siswa lainnya. Hal tersebut dikarenakan siswa baru merasakan proses pembelajaran yang berbeda dari biasanya.

Hasil pengamatan dan diskusi dengan observer untuk mengevaluasi proses pembelajaran berlangsung pada siklus I timbul beberapa permasalahan, maka disusunlah rencana perbaikan untuk dilaksanakan pada siklus II. Berikut ini refleksi siklus I berdasarkan hasil observasi terhadap siswa dan guru adalah sebagai berikut :

1) penggunaan waktu yang kurang efektif dalam pembelajaran sehingga tidak sesuai dengan rencana pelaksanaan pembelajaran.

2) masih kurangnya keaktifan siswa dan masih banyak siswa yang bercanda pada saat kegiatan belajar mengajar berlangsung.

3) guru harus lebih tegas terhadap siswa yang masih kurang aktif dan masih serimg bercanda pada saat kegiatan belajar mengajar.

\section{Siklus II}

Pembelajaran tindakan siklus II disusun berdasarkan hasil observasi dan refleksi yang dilakukan pada tindakan siklus I. Masalah yang terindentifikasi dijadikan sebagai bahan awal untuk menyusun skenario pembelajaran siklus II. Hasil refleksi dari siklus I dijadikan rancangan untuk perbaikan pada pelaksanaan siklus II. Pada siklus II ini konsep masih sama yaitu ekosistem akan tetapi berbeda materi.

Kegiatan pembelajaran pada tindakan siklus II berisi kegiatan pembelajaran yang berpedoman pada skenario pembelajaran siklus II. Sebelum pelaksanaan pembelajaran diadakan tes awal siklus II dan 
Bioedusiana

Vol. 02, No. 01, Sep 2017

ISSN $2477-5193$

setelah selesai pembelajaran siklus II, telah diperoleh berdasarkan tes siklus kemudian dilakukan tes akhir siklus II.

II.Berikut ini adalah hasil data yang

Tabel 2. Jumlah skor dan rata-rata pre-test dan post-test pada siklus II

\begin{tabular}{lcc}
\hline Data & Pre-test & Post-test \\
\hline $\begin{array}{l}\text { Jumlah } \\
\text { Skor }\end{array}$ & 321 & 409 \\
\hline Rata-rata & 7,30 & 9,30 \\
\hline
\end{tabular}

Berdasarkan data pada tabel 2 . terlihat peningkatan rata-rata hasil belajar siswa. Akan tetapi masih ada siswa yang nilai tes akhirnya (posttest) masih dibawah kriteria ketuntasan minimal, walaupun tidak sebanyak pada siklus I. Sebelum masuk ke siklus III, diadakan remedial terhadap siswa-siswa tersebut dengan kembali melakukan perlakuan di luar jam pelajaran sekolah dan kembali melakukan tes dengan soal yang sama dengan soal tes akhir (post-test) pada siklus II.

Hasil observasi terhadap guru terlihat guru sudah menyiapkan bahan dan sumber belajar dengan baik. Guru juga sudah dapat melaksanakan kegiatan pembelajaran dengan baik, dalam melaksanakan dengan sistematis dan baik dalam mengelola waktu. Akan tetapi guru masih kurang tegas dalam mengelola kelas dan melakukan keterlibatan siswa dalam proses pembelajaran, sehingga masih terlihat beberapa siswa yang bercanda.

Hasil observasi terhadap siswa semua siswa hadir dalam kegiatan pembelajaran. Pada siklus II ini sudah terlihat sudah mulai berani dalam mengemukakan pendapat dan diskusi aktif pada kelompok nya. Siswa juga memperhatikan apa yang disampaikan oleh guru dengan sangat antusias. secara umum siswa sangat tertarik dalam penyampaian materi yang diberikan oleh guru dengan bantuan media powerpoint. akan tetapi pada saat diskusi kelompok dalam mengerjakan lembar kerja siswa, masih ada siswa yang bercanda dan tidak fokus pada kerja sama kelompoknya. Pada siklus II ini siswa pun mulai sedikit berani dalam mengemukakan pendapatnya.

Hasil pengamatan dan diskusi dengan observer proses pembelajaran berlangsung pada siklus I secara umum diperbaiki dan dilaksanakan pada tindakan siklus II. Maka disusunlah rencana perbaikan untuk dilaksanakan pada tindakan siklus III Berikut ini refleksi pada siklus II berdasarkan hasil observasi terhadap guru dan siswa.

1) persiapan alat dan bahan pembelajaran sudah cukup baik akan tetapi masih perlu ditingkatkan dalam kefektifan waktunya. 
Bioedusiana

Vol. 02, No. 01, Sep 2017

ISSN $2477-5193$

2) guru harusnya lebih tegas lagi terhadap beberapa siswa yang masih suka bercanda dalam kegiatan belajar mengajar.

3) pembuatan media powerpoint lebih dibuat menarik agar siswa tidak jenuh dalam penyampaian.

\section{Siklus III}

Pembelajaran tindakan siklus III disusun berdasarkan hasil observasi dan refleksi yang dilakukan pada tindakan siklus II. Masalah yang terindentifikasi dijadikan sebagai bahan awal untuk menyusun skenario pembelajaran siklus III. Hasil refleksi

dari siklus II dijadikan rancangan untuk perbaikan pada pelaksanaan siklus III.

Kegiatan pembelajaran pada tindakan siklus III berisi kegiatan pembelajaran yang berpedoman pada skenario pembelajaran siklus III. Sebelum pelaksanaan pembelajaran diadakan tes awal siklus III dan setelah selesai pembelajaran siklus III, kemudian dilakukan tes akhir siklus III.

Berikut ini adalah hasil data yang telah diperoleh berdasarkan tes siklus III.

Tabel 3. Jumlah skor dan rata-rata pre-test dan post-test pada siklus III

\begin{tabular}{lcc}
\hline Data & Pre-test & Post-test \\
\hline $\begin{array}{l}\text { Jumlah } \\
\text { Skor }\end{array}$ & 338 & 414 \\
\hline Rata-rata & 7,68 & 9,41 \\
\hline
\end{tabular}

Berdasarkan data pada tabel 3, pada siklus III terlihat peningkatan hasil belajar siswa. Pada siklus III terlihat tidak ada siswa yang mempunyai nilai di bawah kriteria ketuntasan minimal yaitu sebesar 75 . Hal ini dikarenakan siswa yang bersemangat dan sungguh-sungguh dalam proses pembelajaran siklus III ini.

Hasil observasi terhadap guru juga terlihat guru sudah efektif dalam mempersiapkan bahan pembelajaran, guru juga sudah bisa membuat siswa tertarik di dalam proses pembelajaran. Penerapan model dan media pembelajaran yang sudah sangat efektif. Serta guru sudah bisa membuat keterlibatan secara aktif siswa terhadap proses belajar mengajar di kelas.

Hasil observasi terhadap siswa terlihat siswa cukup akrtif dan ikut berpartisipasi aktif dalam setiap langkah-langkah model pembelajaran yang digunakan. Siswa juga sangat antusias dalam memperhatikan penjelasan yang diberikan oleh guru. Secara kesuluruhan sudah dapat menstimulasi siswa dengan baik, dalam bekerja kelompok pun siswa telihat lebih termotivasi dan antusias sehingga proses pembelajaran dapat berlangsung sesuai yang diharapkan.

Hasil pengamatan dan diskusi dengan observer proses pembelajaran 
Bioedusiana

Vol. 02, No. 01, Sep 2017

ISSN $2477-5193$

berlangsung pada siklus II secara umum telah diperbaiki dan dilaksanakan pada tindakan siklus III. Hasil refleksi pada siklus III berdasarkan hasil observasi terhadap guru dan siswa terlihat pelaksanaan pembelajaran dapat berlangsung dengan baik.

\section{Hasil Analisis Wawancara Siswa}

Berdasarkan hasil wawancara terhadap seluruh siswa kelas VII D SMP Negeri 2 Tasikmalaya, setelah penerapan model pembelajaran kooperatif tipe student teams achievemnt divisions dengan bantuan media powerpoint, menurut para siswa bahwa model pembelajaran kooperatif dengan bantuan media ini lebih baik diterapkan dalam pembelajaran, karena sangat efektif, menyenangkan, pada saat berdiskusi dengan dengan teman sekelompoknya, membuat para siswa lebih termotivasi dalam menyimak pembelajaran maupun menjawab pertanyaan yang diberikan oleh guru. Berbeda dengan penggunaan pembelajaran tanpa menggunakan model pembelajaran kooperatif dan tanpa media yang cenderung membuat siswa menjadi jenuh dalam proses pembelajaran.

\section{KESIMPULAN}

Berdasarkan hasil penelitian, pengolahan dan analisis data yang telah dilakukan pada penelitian, dapat disimpulkan bahwa pembelajaran dengan penerapan model pembelajaran kooperatif tipe student team achievement divisions dengan

bantuan powerpoint dapat meningkatkan hasil belajar siswa.

Selama proses pembelajaran berlangsung terlihat perkembangan siswa menjadi aktif, baik dalam bertanya, diskusi bersama teman sekelompok dan juga dalam mengemukakan pendapat. Hal ini disebabkan karena model pembelajaran dan media yang digunakan membuat siswa lebih semangat dalam belajar bersama teman sekelompok dan juga pada saat penyampaian materi dengan menggunakan media powerpoint. penggunaan model pembelajaran kooperatif disertai media juga dapat memberikan pengalaman konkret, motivasi belajar dan juga daya serap serta aktivitas belajar siswa.

\section{DAFTAR PUSTAKA}

Ali, Muhammad. (2008). Guru Dalam Proses Belajar Mengajar. Bandung: Sinar Baru Algesindo.

Arikunto, Suharsimi. (2006). Prosedur Penelitian Suatu Pendekatan Praktek. Jakarta: Rineka Cipta.

------------. (2008). Penelitian Tindakan Kelas. Jakarta: Bumi Aksara.

Arsyad, Azhar. (2010). Media Pembelajaran. Jakarta: RajaGrafindo Persada.

Djamarah, Bahri Syaiful dan Aswan Zain. (2006) Strategi Belajar Mengajar. Jakarta: Rineka Cipta.

Isjoni. (2009). Pembelajaran Kooperatif. Yogyakarta: Pustaka Pelajar.

Lie, Anita. (2002). Cooperative Learning. Jakarta: Grasindo. 
Bioedusiana

Vol. 02, No. 01, Sep 2017

ISSN $2477-5193$

Sanjaya, Wina. (2006). Strategi Pembelajaran Beroreintasi Standar Proses Pendidikan. Bandung: Kencana Prenada Media Group.

Slameto. (2003). Belajar dan Faktorfaktor yang Mempengaruhinya. Jakarta : Rineka cipta.

Slavin, Robert E. (2010). Cooperative Learning. Bandung: Nusa Media.

Sudjana, Nana. (2008). Penilaian Hasil Proses Belajar Mengajar. Bandung : Remaja Rosdakarya.

Surahman, Endang. (2005). Classroom Action Research.
Diktat Mata Kuliah Pendidikan Biologi II. Program Studi Pendidikan Biologi, Fakultas Keguruan dan Ilmu Pendidikan Universitas Tasikmalaya: Siliwangi dipublikasikan.

Uno, Hamzah B. (2009). Model Pembelajaran. Jakarta: Bumi Aksara.

Yamin, Martinis. (2008). Paradigma Pendidikan Konstruktivistik. Jakarta: Gaung Persada Press. 